\title{
SIFAT KIMIA TANAH, POPULASI BAKTERI PELARUT FOSFAT, DAN HASIL CABAI PADA APLIKASI BEBERAPA JENIS MULSA PADA INCEPTISOL NGEMPLAK, BOYOLALI
}

\author{
Fahrizal Yusuf Bahtiar'), Sudadi' ${ }^{2)}$ dan Vita Ratri Cahyani2 ${ }^{2 *}$ \\ 1)Program Studi Agroteknologi, Fakultas Pertanian, Universitas Sebelas Maret \\ ${ }^{2}$ Program Studi Ilmu Tanah, Fakultas Pertanian, Universitas Sebelas Maret \\ *Corresponding author: vitaratri@staff.uns.ac.id
}

\begin{abstract}
Mulch was often applied on chili pepper cultivation. It aimed to cover the soil from various factors which can reduce the yield. This research aims to study the effect of various types of mulch (silver-black plastic and straw) to soil chemical properties, population of PSB, and chili pepper yield (harvest time, weight of dry plant biomass, and weight of fresh fruit per plant), also to study the correlation between the population of PSB with chili pepper yield. The research has been conducted from December 2015 until October 2016, on an inceptisol field in Ngemplak, Boyolali. The variables of this research are soil properties ( $p H$, organic-carbon, total- $N$, available- $P$, and exchangeable-K), total-PSB, and chili pepper yield (harvest time, a weight of dry plant biomass, and weight of fresh fruit per plant). The result showed that various types of mulch application significantly increased soil-pH, soil total- $N$, soil available-P, total-PSB, a weight of dry plant biomass, a weight of fresh fruit per plant, and fastened harvest time. It also tends to increase organic-carbon and soil exchangeable-K. There were strong correlations between total-PSB and harvest time, a weight of dry plant biomass, and weight of fresh fruit per plant. The best result showed by silver-black plastic mulch application.
\end{abstract}

Keywords: Chili pepper yield; Phosphate solubilizer bacteria; Silver-black plastic mulch; Soil chemical properties; Straw mulch

Cite this as: Bahtiar, F., Sudadi, S., \& Cahyani, V. 2017. Sifat Kimia Tanah, Populasi Bakteri Pelarut Fosfat, dan Hasil Cabai pada Aplikasi Beberapa Jenis Mulsa pada Inceptisol Ngemplak, Boyolali. Caraka Tani: Journal of Sustainable Agriculture. 32(2), 75-83. doi: http://dx.doi.org/10.20961/carakatani.v32i2.13418

\section{PENDAHULUAN}

Cabai (Capsicum annuum L.) merupakan salah satu komoditas sayuran yang penting bagi masyarakat Indonesia. Berbagai olahan pangan hampir selalu ada unsur cabai di dalamnya. Permintaan terhadap cabai yang semakin tinggi menuntut aspek budidaya untuk meningkatkan produktivitas. Pengetahuan mengenai syarat tumbuh mutlak untuk dipahami agar hasil cabai optimal. Syarat tumbuh cabai yaitu pada tanah yang bertekstur lempung, lempung berpasir, atau lempung berdebu, memiliki kandungan bahan organik yang tinggi, $\mathrm{pH}$ tanah pada kisaran 5,5 6,5, dan lokasi penanaman dianjurkan memiliki intensitas cahaya matahari yang tinggi namun kelembaban tanahnya tidak terlalu tinggi (Hayati, 2016). Apabila kriteria lahan tersebut tidak terpenuhi maka produktivitas cabai rendah.
Lahan di Kecamatan Ngemplak, Kabupaten Boyolali dengan jenis tanah inceptisol memiliki sifat kimia tanah yang kurang memadai untuk budidaya cabai. Sifat kimia tanah yang terdiri dari berbagai parameter seperti $\mathrm{pH}, \mathrm{C}$-organik, $\mathrm{N}$ total, P-tersedia, dan K-tertukar merupakan faktor yang sangat memengaruhi produksi tanaman. Setiap parameter memiliki permasalahan masingmasing.

Salah satu parameter yaitu $\mathrm{P}$ (Fosfor) memiliki kendala dari segi ketersediaannya untuk tanaman. Tanah merupakan habitat mikroorganisme, termasuk di dalamnya adalah BPF (Bakteri Pelarut Fosfat). BPF telah diketahui mampu melarutkan fosfor yang terikat sehingga menjadi P-tersedia bagi tanaman. Melalui peran BPF ini diharapkan mampu meningkatkan ketersediaan fosfor bagi tanaman. 
Permasalahan lain yaitu sebagai negara beriklim tropis Indonesia mengalami dua musim dalam satu tahun, yaitu musim penghujan dan musim kemarau. Iklim merupakan faktor penting dalam budidaya cabai, sehingga faktor iklim yang menjadi pembatas produksi cabai harus diatasi dengan baik, salah satunya dengan teknik pemulsaan. Mulsa dapat melindungi tanah dari daya rusak air hujan sehingga mampu mempertahankan keberadaan bahan organik tanah. Salah satu fungsi mulsa ialah memperkecil erosi pada suatu areal pertanaman (Fardani, 2012). Selain itu, menurut Noorhadi dan Sudadi (2003) pemberian mulsa berpengaruh nyata terhadap penurunan suhu tanah dan suhu udara, peningkatan kelembaban udara, peningkatan tinggi tanaman dan menambah luas daun.

Oleh karena itu perlu dilakukan penelitian ini untuk mengetahui pengaruh aplikasi beberapa jenis mulsa terhadap sifat kimia tanah, populasi BPF, dan hasil cabai, serta untuk mengetahui hubungan antara populasi BPF dengan hasil cabai.

\section{METODE PENELITIAN}

Analisis tanah awal dan pupuk kandang dilakukan pada Agustus 2015, sedangkan analisis tanah akhir dilakukan pada November 2016 Januari 2017 bertempat di Laboratorium Kimia dan Kesuburan Tanah, Fakultas Pertanian, Universitas Sebelas Maret. Analisis terhadap sifat kimia tanah dilakukan sebelum dan setelah budidaya cabai. Sifat kimia tanah yang diamati meliputi $\mathrm{pH}, \mathrm{C}$-organik, N-total, P-tersedia, Ktertukar, serta tekstur sebelum budidaya cabai. Selain itu pupuk kandang sapi yang dijadikan pupuk dasar juga dianalisis $\mathrm{pH}, \mathrm{C}$-organik, $\mathrm{N}$ total, P-total, dan K-totalnya. Analisis kimia dilakukan berdasarkan Petunjuk Teknis Analisis Kimia Tanah, Tanaman, Air, dan Pupuk dari Balai Penelitian Tanah 2005.

Analisis total BPF pada tanah awal dan pupuk kandang dilakukan pada Agustus 2015, sedangkan analisis total BPF akhir dilakukan pada November 2016 bertempat di Laboratorium Biologi dan Bioteknologi Tanah, Fakultas Pertanian, Universitas Sebelas Maret. Analisis total bakteri pelarut fosfat dilakukan pada tanah sebelum budidaya, pupuk kandang sapi, dan rizosfer setelah panen, Media yang digunakan untuk analisis total BPF adalah media pikovskaya yang ditambahkan ketocazazole (anti jamur). Sampel diencerkan dalam garam fisiologis secara bertingkat (pengenceran $10^{-1}-10^{-7}$ ). Pengenceran $10^{-3}, 10^{-5}$, dan $10^{-7}$ ditumbuhkan pada cawan petri berisi media. Pengamatan dilakukan pada hari kedua setelah tanam. Koloni BPF memiliki ciriciri yaitu membentuk zona bening (holozone) pada media.

Percobaan lapang dilakukan pada lahan tegalan dengan jenis tanah inceptisol di Ngemplak, Boyolali pada Desember 2015 November 2016. Bahan-bahan yang digunakan adalah tanah dan pupuk kandang untuk media pembibitan, benih cabai hibrida PM999, mulsa plastik hitam perak, mulsa jerami, pupuk NPK (15:15:15), pupuk $\mathrm{KCl} 60 \%$, pestisida rumba 500 EC, dan dithane M-45. Alat-alat yang digunakan adalah alat-alat untuk budidaya cabai. Percobaan ini merupakan penelitian pendekatan yang menggunakan Rancangan Acak Lengkap (RAL) dengan 1 faktor, 3 taraf, dan 3 ulangan.

Pelaksanaan penelitian terdiri dari pembibitan, persiapan lahan, pemupukan dasar, pemasangan mulsa, penanaman, penyulaman, pemupukan susulan, pewiwilan, pengendalian organisme pengganggu tanaman, dan panen. Variabel pengamatan yaitu umur panen, bobot segar buah per tanaman, dan bobot kering brangkasan. Data hasil penelitian dianalisis dengan uji $\mathrm{F} 5 \%$, dilanjutkan uji Duncan's Multiple Range Test (DMRT) 5\%, serta dilakukan uji korelasi Pearson terhadap variabel total BPF dan hasil cabai.

\section{HASIL DAN PEMBAHASAN}

Menurut Notohadiprawiro et al. (1984) kesuburan tanah adalah mutu tanah untuk bercocok tanam, yang ditentukan oleh interaksi sejumlah sifat fisika, kimia, dan biologi bagian tubuh tanah yang menjadi habitat akar-akar aktif tanaman. Lahan penelitian yang digunakan memiliki tekstur pasir, reaksi agak masam, Corganik sangat rendah, $\mathrm{N}$-total rendah, P-tersedia sangat rendah, K-tertukar rendah, dan memiliki total BPF 2,6x10 $\mathrm{cfu}^{7} \mathrm{gram}^{-1}$ (Tabel 1). Kondisi lahan yang demikian menunjukkan kesuburan yang rendah.

Pupuk dasar dalam penelitian ini adalah kombinasi pupuk kandang sapi dosis 20 ton/ha dan pupuk NPK (15:15:15) dosis $250 \mathrm{~kg} / \mathrm{ha}$. Pupuk susulan diberikan pada 14 HST, 28 HST, dan seterusnya (tiap 14 hari) dengan kombinasi 450 gram NPK (15:15:15) dilarutkan dalam 10,8 liter air, volume pemupukan yaitu 200 $\mathrm{ml} /$ tanaman. Aplikasi pupuk menggunakan teknik 
irigasi tetes/dikocor pada sekitar perakaran tanaman. Irigasi tetes merupakan sistem pemberian air pada tanaman secara langsung baik pada permukaan tanah maupun di dalam tanah melalui tetesan-tetesan secara sinambung dan perlahan (Keller dan Bleisner 1990). Saat tanaman mulai berbunga ditambahkan pupuk $\mathrm{KCl}$ $60 \%$ sebanyak 120 gram ke dalam komposisi sebelumnya.

Tabel 1. Sifat Tanah Awal Lahan Pertanaman Cabai

\begin{tabular}{|c|c|c|}
\hline Variabel Pengamatan & Hasil & Harkat \\
\hline Tekstur & 10 & Pasir $^{* * *}$ \\
\hline $\mathrm{pH} \mathrm{H} \mathrm{H}_{2} \mathrm{O}$ & 6,4 & Agak Masam* \\
\hline C organik $(\%)$ & 0,67 & Sangat rendah* \\
\hline $\mathrm{N}$ total $(\%)$ & 0,13 & Rendah* $^{*}$ \\
\hline P tersedia (ppm) & 4 & Sangat rendah* \\
\hline K tertukar (ppm) & 16 & Rendah $^{* *}$ \\
\hline $\begin{array}{l}\text { Total BPF } \\
\left(\mathrm{cfu} \operatorname{gram}^{-1}\right)\end{array}$ & $2,6 \times 10^{7}$ & - \\
\hline
\end{tabular}

Keterangan: Pengharkatan oleh "Balittan (2005), ${ }^{* *}$ Amacher et al. (2007), ${ }^{* * *}$ USDA

Pupuk kandang (pukan) padat yaitu kotoran ternak yang berupa padatan baik belum dikomposkan maupun sudah dikomposkan sebagai sumber hara terutama $\mathrm{N}$ bagi tanaman dan dapat memperbaiki sifat kimia, biologi, dan fisik tanah (Hartatik dan Widowati, 2006). Hasil analisis menunjukkan nilai $\mathrm{pH} 8,0, \mathrm{C}$ organik $20,50 \%, \mathrm{~N}$ total $1,02 \%$, P total $0,48 \%$, K total $0,53 \%$, dan total BPF $1,9 \times 10^{9} \mathrm{cfu} \mathrm{gram}^{-1}$ (Tabel 2). Dengan demikian pupuk kandang tersebut memiliki C/N rasio 20,09. Menurut Permentan No. 70 tahun 2011 tentang Pupuk Organik, Pupuk Hayati, dan Pembenah Tanah, standar mutu pupuk organik yaitu memiliki $\mathrm{C} / \mathrm{N}$ rasio $15-25$, dengan $\mathrm{C}$ organik minimal $15 \%$.

Tabel 2. Kandungan Pupuk Kandang

\begin{tabular}{|c|c|}
\hline Variabel Pengamatan & Hasil \\
\hline $\mathrm{pH} \mathrm{H} \mathrm{H}_{2} \mathrm{O}$ & 8,0 \\
\hline Kadar air (\%) & 70,65 \\
\hline $\mathrm{C}$ organik $(\%)$ & 20,50 \\
\hline $\mathrm{N}$ total $(\%)$ & 1,02 \\
\hline $\mathrm{P}$ total $(\%)$ & 0,48 \\
\hline $\mathrm{K}$ total $(\%)$ & 0,53 \\
\hline Total BPF (cfu gram $\left.{ }^{-1}\right)$ & $1,9 \times 10^{9}$ \\
\hline
\end{tabular}

\section{Pengaruh Aplikasi beberapa Jenis Mulsa terhadap Sifat Kimia Tanah}

Reaksi tanah dikategorikan menjadi sangat masam, masam, netral, basa, dan sangat basa tergantung dari nilai $\mathrm{pHnya} . \mathrm{pH}$ tanah dipengaruhi berbagai faktor di antaranya batuan induk dari tanah tersebut dan aktivitas perombakan bahan organik yang menghasilkan asam-asam organik (Sukristiyonubowo et al., 1993).

Ada beda nyata dari nilai $\mathrm{pH}$ yang dihasilkan antara mulsa plastik hitam-perak dengan tanpa mulsa. Gambar 1 memperlihatkan nilai $\mathrm{pH}$ tertinggi dihasilkan oleh mulsa plastik hitamperak yaitu 6,4, pH terendah pada tanpa mulsa yaitu 6,1, sementara pada mulsa jerami yaitu 6,2. Mulsa plastik hitam-perak menghasilkan $\mathrm{pH}$ tanah yang lebih tinggi daripada mulsa jerami karena jerami adalah sumber bahan organik yang akan terdekomposisi menghasilkan asam organik. Asam-asam organik tersebut mengakibatkan kemasaman pada mulsa jerami lebih tinggi $(\mathrm{pH}$ lebih rendah).

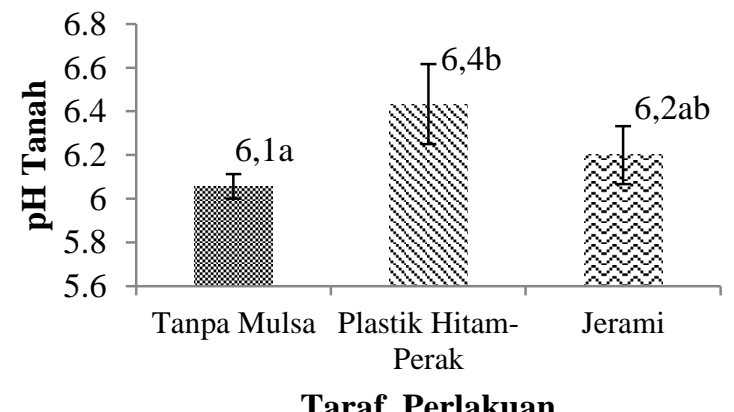

Gambar 1. Pengaruh Jenis Mulsa terhadap pH Tanah Inceptisol yang ditanami Cabai

Bahan organik tanah merupakan penimbunan biomassa, terdiri atas sisa-sisa dan pembentukan baru dari sisa tumbuhan maupun hewan (Triyono, 2007).

Aplikasi beberapa jenis mulsa tidak memberikan pengaruh nyata terhadap C-organik tanah. Dilihat dari nilai rata-ratanya C-organik tertinggi adalah $0,83 \%$ pada mulsa jerami, Corganik terendah adalah $0,75 \%$ pada tanpa mulsa, sedangkan pada mulsa plastik hitam perak Corganiknya 0,79\% (Gambar 2). Dengan demikian, kandungan C-organik tanah setelah aplikasi mulsa lebih tinggi jika dibandingkan C-organik tanah awal. 


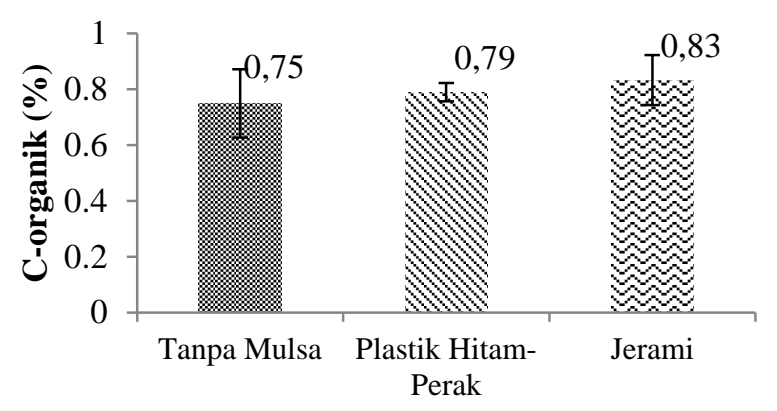

Taraf Perlakuan

Gambar 2. Pengaruh Jenis Mulsa terhadap C-organik Tanah Inceptisol yang ditanami Cabai

C-organik tanah yang paling tinggi dihasilkan oleh mulsa jerami, merupakan hasil dari manifestasi perombakan jerami selama musim tanam. Romic et al. (2003) mengungkapkan bahwa mulsa organik merupakan bahan permeabel, bahan biodegradabel, dan karena itu secara bertahap dapat kehilangan fungsi mulsanya. Jerami yang semula sebagai mulsa dengan adanya proses dekomposisi menjadi sumber bahan organik bagi tanah.

Nitrogen $(\mathrm{N})$ merupakan unsur hara esensial bagi tanaman. $\mathrm{N}$ dibutuhkan dalam jumlah yang banyak (Hanafiah et al., 2009). Lahan penelitian memiliki kandungan $\mathrm{N}$-total tanah yang rendah. Hal ini sesuai dengan pernyataan Nariratih et al. (2013) bahwa Inceptisol bertekstur agak kasar mengandungan bahan organik, unsur $\mathrm{N}$, dan unsur hara lain yang rendah.

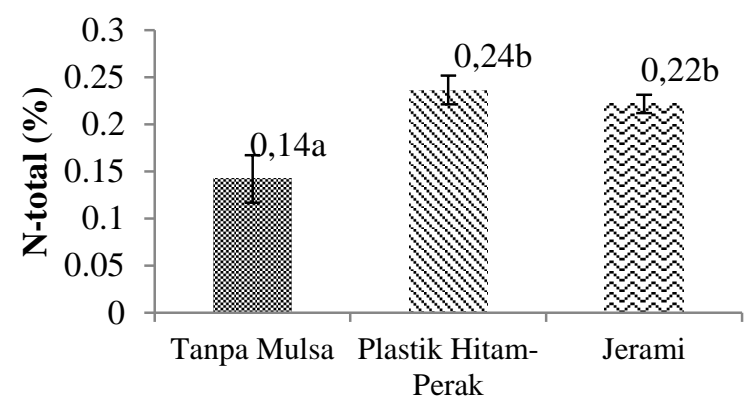

Taraf Perlakuan

Gambar 3. Pengaruh Jenis Mulsa terhadap NTotal Tanah Inceptisol yang ditanami Cabai

Hasil uji jarak berganda Duncan menunjukkan ada beda nyata $\mathrm{N}$-total tanah yang dihasilkan antara mulsa plastik hitam perak dan mulsa jerami dengan tanpa mulsa, namun antara mulsa plastik dan mulsa jerami tidak beda nyata. Gambar 3 memperlihatkan $\mathrm{N}$-total tertinggi adalah $0,24 \%$ terdapat pada mulsa plastik, N-total terendah adalah $0,14 \%$ pada tanpa mulsa, sedangkan pada mulsa jerami N-total tanahnya $0,22 \%$. Jika dibandingkan dengan tanah awal (Tabel 1), maka ketiga taraf menghasilkan peningkatan $\mathrm{N}$-total tanah. Menurut Fang et al. (2008) pemulsaan mampu meningkatkan $\mathrm{N}$-total tanah secara signifikan sepanjang musim tanam dan bukan musim tanam. Mulsa berperan menutupi tanah sehingga mampu mengurangi hilangnya nitrogen ke udara.

Fosfor diserap tanaman dalam bentuk $\mathrm{H}_{2} \mathrm{PO}_{4}{ }^{-}$ dan $\mathrm{HPO}_{4}{ }^{2-}$. Fosfor merupakan komponen struktural dari sejumlah senyawa penting, molekul pentransfer energi ADP dan ATP (adenosin di- dan trifosfat), NAD, NADPH, dan senyawa sistem informasi genetik DNA dan RNA (asam deoksiribo dan ribonukleat) (Gardner et al., 1991).

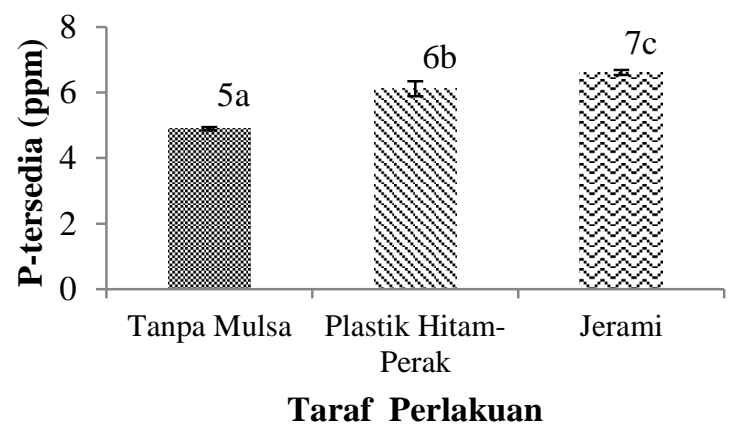

Gambar 4. Pengaruh Jenis Mulsa terhadap Ptersedia Tanah Inceptisol yang ditanami Cabai

Terdapat beda nyata berdasarkan uji jarak berganda Duncan dari pengaruh jenis mulsa terhadap P-tersedia tanah. Nilai P-tersedia dari masing-masing taraf tersaji pada Gambar 4 yang menunjukkan hasil tertinggi adalah $7 \mathrm{ppm}$ pada mulsa jerami, hasil terendah adalah 5 ppm pada tanpa mulsa, sedangkan mulsa plastik hitam perak P-tersedianya 6 ppm. Menurut Fang et al. (2008) bedengan dengan mulsa jerami memiliki kandungan P-tersedia yang jauh lebih tinggi dibanding dengan bedengan tanpa mulsa. Ptersedia pada perlakuan mulsa plastik hitam-perak dan jerami lebih tinggi daripada tanpa mulsa secara kimiawi berkaitan dengan $\mathrm{pH}$ tanah. Tanpa mulsa memiliki $\mathrm{pH}$ terendah dibandingkan mulsa 
plastik hitam-perak dan mulsa jerami (gambar 1). Menurut Notohadiprawiro (1983) pada $\mathrm{pH}$ rendah terjadi kekahatan unsur hara makro. P-tersedia tertinggi terdapat pada mulsa jerami juga dikarenakan pada mulsa jerami memiliki total BPF tertinggi (gambar 6).

Aplikasi beberapa jenis mulsa tidak memberikan pengaruh nyata terhadap K-tertukar tanah. Namun terjadi peningkatan jika dibandingkan dengan tanah awal (Tabel 1). Gambar 5 memperlihatkan nilai K-tertukar tertinggi adalah $60 \mathrm{ppm}$ pada mulsa plastik hitam perak, yang terendah adalah $54 \mathrm{ppm}$ pada tanpa mulsa, sedangkan pada mulsa jerami nilai Ktertukarnya $55 \mathrm{ppm}$. Menurut Amacher et al. (2007) nilai K-tertukar dari semua taraf tergolong rendah $(<100 \mathrm{ppm})$ dan merupakan indikasi terjadinya defisiensi. Munir (1996) mengungkapkan bahwa di dalam tanah $\mathrm{K}$ sering mengalami defisiensi.

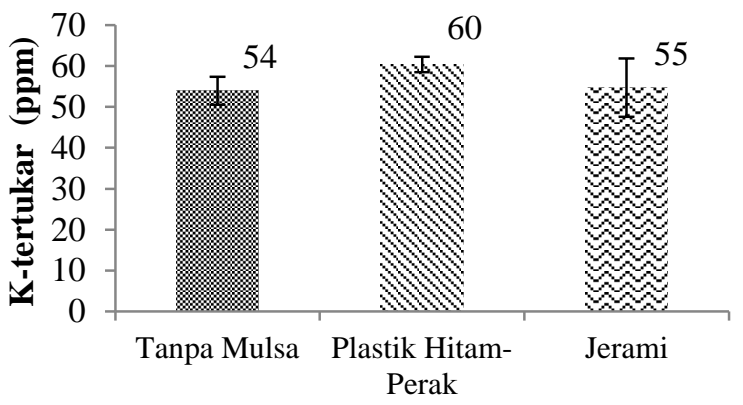

Taraf Perlakuan

Gambar 5. Pengaruh Jenis Mulsa terhadap Ktertukar Tanah Inceptisol yang ditanami Cabai

Inceptisol dengan bahan induk abu vulkan, kaya akan mineral alofan yang memiliki kemampuan tinggi dalam menjerap $\mathrm{K}$, namun tidak mengandung K. K-tertukar pada mulsa plastik hitam-perak lebih tinggi daripada mulsa jerami karena setelah mulsa jerami terdekomposisi akan kehilangan fungsinya sebagai penutup tanah, sehingga kalium lebih mudah hilang akibat erosi maupun tercuci.

\section{Pengaruh Aplikasi beberapa Jenis Mulsa terhadap Populasi BPF}

Bahan organik yang terdekomposisi akan menghasilkan $\mathrm{P}$ yang hanya sedikit tersedia bagi tanaman karena di tanah sifat $\mathrm{P}$ adalah mudah terjerap dengan bagian-bagian anorganik dan membentuk senyawa yang relatif sukar larut. Menurut Premono (1994) enzim fosfatase berperan utama dalam melepaskan $\mathrm{P}$ dari ikatan P-organik. Enzim ini banyak dihasilkan oleh jasad renik tanah, terutama yang bersifat heterotrof.

Peran bakteri pelarut fosfat menjadi penting dalam meningkatkan P-tersedia. Basyaruddin (1982) menyatakan bahwa proses utama pelarutan senyawa fosfat sukar larut karena adanya produksi asam organik dan sebagian asam anorganik oleh mikroba yang dapat berinteraksi dengan senyawa P-sukar larut dari kompleks $\mathrm{Al}^{-}, \mathrm{Fe}-, \mathrm{Mn}^{-}$, dan $\mathrm{Ca}^{-}$. Mekanisme pelarutan $\mathrm{P}$ dari senyawa yang sukar larut terkait erat dengan aktivitas mikroba bersangkutan dalam menghasilkan asam-asam organik seperti asam sitrat, glutamat, suksinat, laktat, oksalat, glioksalat, malat, fumarat, tartarat, dan ketobutirat (Alexander, 1978).

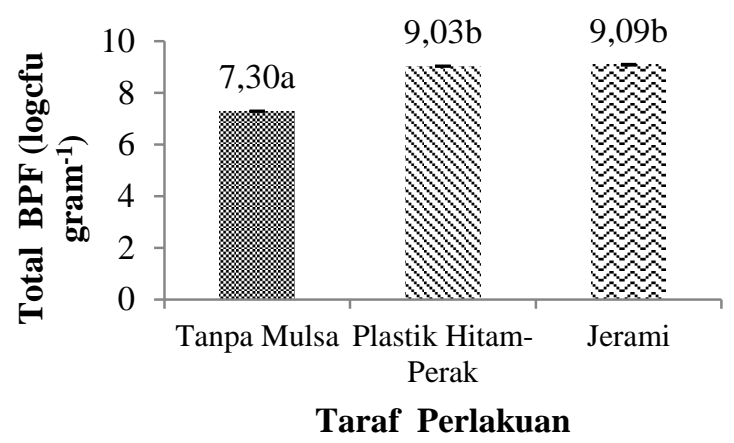

Gambar 6. Pengaruh Jenis Mulsa terhadap total BPF pada Tanah Inceptisol yang ditanami Cabai

Hasil uji jarak berganda Duncan menunjukkan adanya beda nyata dari pengaruh jenis mulsa terhadap populasi BPF. Nilai total BPF tertinggi yaitu $1,2 \times 10^{9}\left(\mathrm{cfu} \mathrm{gram}^{-1}\right)$ atau 9,09 (log cfu gram $^{-1}$ ) pada mulsa jerami, total BPF terendah yaitu $1,9 \times 10^{7}\left(\mathrm{cfu} \mathrm{gram}^{-1}\right)$ atau 7,30 (log cfu gram $^{-1}$ ) pada tanpa mulsa, sedangkan pada mulsa plastik hitam perak total BPF yaitu 1,2 X109 (cfu gram $^{-1}$ ) atau 9,03 (log cfu gram $\left.{ }^{-1}\right)$ (Gambar 6). Jika dibandingkan dengan tanah awal maka total BPF setelah panen mengalami peningkatan. Total BPF pada perlakuan mulsa lebih tinggi dibandingkan dengan tanpa mulsa karena mulsa menjadikan iklim mikro tanah yang stabil sehingga BPF berkembang dengan baik. Menurut Diaz-Perez (2009) mulsa menghasilkan suhu rizosfer tetap rendah pada saat kondisi siang hari yang panas dan menghasilkan suhu rizosfer tetap hangat saat kondisi malam hari dingin. Tarara 
(2000) melaporkan bahwa bagian atas yang berwarna perak secara signifikan mampu memantulkan radiasi surya terutama infra merah.

\section{Pengaruh Aplikasi beberapa Jenis Mulsa terhadap Hasil Cabai}

Panen merupakan kegiatan memetik atau menuai hasil budidaya pertanian. Waktu yang diperlukan tanaman sejak ditanam hingga bisa dipetik hasilnya disebut sebagai umur panen dalam satuan Hari Setelah Tanam (HST). Cabai memiliki umur panen yang bervariasi tergantung varietasnya. Penelitian ini menggunakan varietas PM-999 dengan kisaran umur panen 90 - 110 HST.

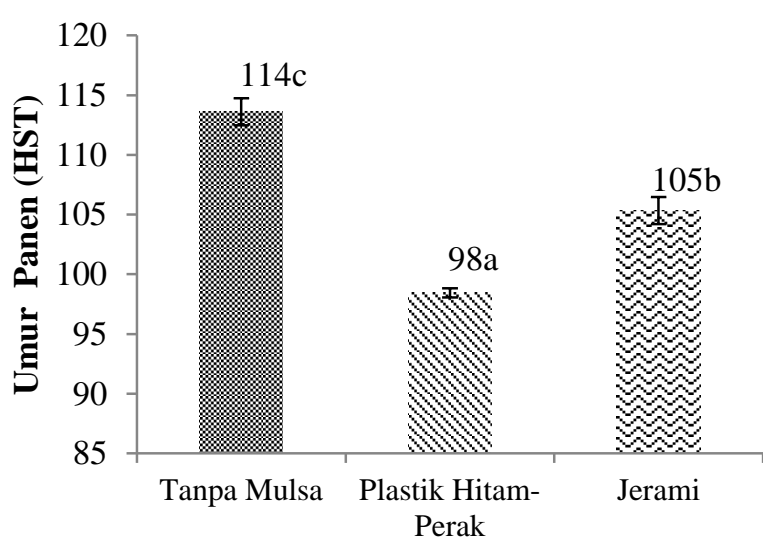

Taraf Perlakuan

Gambar 7. Pengaruh Jenis Mulsa terhadap Umur Panen Cabai

Hasil uji jarak berganda Duncan menunjukkan adanya beda nyata dari pengaruh jenis mulsa terhadap umur panen. Umur panen terlama berdasarkan gambar 7 adalah 114 HST pada tanpa mulsa, yang tercepat adalah 98 HST pada mulsa plastik, sedangkan pada mulsa jerami umur panennya 105 HST. Aplikasi mulsa mempercepat panen dibandingkan dengan tanpa aplikasi mulsa sesuai dengan pernyataan Lamont (1993) yang melaporkan penggunaan mulsa anorganik antara lain dapat mempercepat tanaman berproduksi dan Vos (1994) yang menyatakan mulsa organik jerami menyebabkan pertumbuhan tanaman dan waktu pembentukan buah lebih cepat.

Cabai dibudidayakan untuk dipanen buahnya. Cabai varietas PM-999 memiliki bentuk buah yang keriting dan ramping dengan warna merah saat buah masak. Varietas ini memiliki kisaran produktivitas 16-24 ton/ha (533-800 gram/tanaman). Berdasarkan keterangan pada kemasan benih, bobot dan potensi hasil tergantung pada lingkungan dan perlakuan budidayanya.

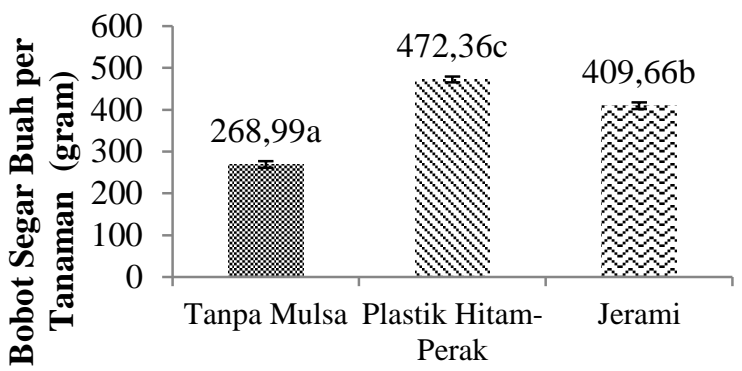

Taraf Perlakuan

Gambar 8. Pengaruh Jenis Mulsa terhadap Bobot Segar Buah per Tanaman

Pengaruh jenis mulsa menghasilkan beda nyata terhadap bobot segar buah per tanaman. Berdasarkan Gambar 8, bobot segar buah per tanaman tertinggi adalah 472,36 gram pada mulsa plastik, yang terendah adalah 268,99 gram pada tanpa mulsa, sedangkan pada mulsa jerami adalah 409,66 gram. Aplikasi mulsa menghasilkan bobot segar buah per tanaman yang jauh lebih tinggi dibandingkan tanpa mulsa. Penggunaan mulsa anorganik dapat meningkatkan hasil per satuan luas (Lamont, 1993). Penggunaan mulsa organik dapat memperbaiki sifat fisik, kimia, dan biologi tanah yang akan mempermudah penyediaan unsur-unsur hara yang dibutuhkan tanaman untuk pembentukan dan perkembangan buah (Creamer et al., 1996).

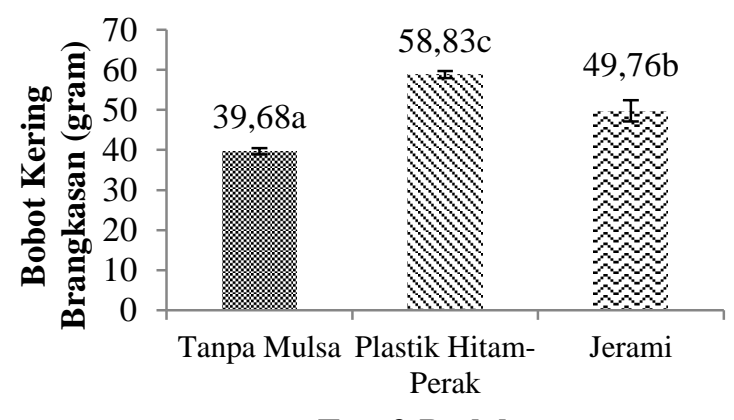

Taraf Perlakuan

Gambar 9. Pengaruh Jenis Mulsa terhadap Bobot Kering Brangkasan

Fotosintesis merupakan proses fisiologis utama dan merupakan landasan dari pembentukan 
hasil tanaman (Zou et al., 2007). Brangkasan kering merupakan akumulasi hasil fotosintat dari fase vegetatif tanaman. Dong et al. (2009) melaporkan bahwa aplikasi mulsa secara signifikan meningkatkan kapasitas fotosintesis daun.

Hasil uji jarak berganda Duncan menunjukkan adanya beda nyata bobot kering brangkasan sebagai pengaruh dari jenis mulsa. Bobot kering brangkasan tertinggi adalah 58,83 gram pada mulsa plastik, yang terendah adalah 39,68 gram pada tanpa mulsa, sedangkan pada mulsa jerami adalah 49,76 gram (Gambar 9). Menurut Hassan et al. (1995) pemulsaan secara praktis meningkatkan produksi cabai, dan mungkin berhubungan dengan kelembaban tanah dan suhu yang optimal, yang meningkatkan hasil tanaman. Liang et al. (2011) menyimpulkan bahwa kombinasi mulsa plastik dan mulsa jerami mampu bekerja baik untuk optimalisasi pertumbuhan tanaman, dan hasil panen cabai.

Korelasi antara Total BPF dengan Umur Panen, Bobot Segar Buah per Tanaman, dan Bobot Kering Brangkasan

Korelasi merupakan salah satu pengujian untuk mengetahui hubungan antara dua varabel atau lebih. Populasi BPF, umur panen, bobot segar buah, dan bobot kering brangkasan merupakan variabel yang diamati pada penelitian ini. Guna mengetahui hubungan antara populasi BPF dengan varabel-variabel hasil cabai tersebut maka dilakukan Uji Korelasi Pearson.

Tabel 3. Uji Pearson antara Populasi BPF dengan Umur Panen, Bobot Segar Buah per Tanaman, dan Bobot Kering Brangkasan

\begin{tabular}{lccc}
\hline Variabel & $\begin{array}{c}\text { Umur } \\
\text { Panen }\end{array}$ & $\begin{array}{c}\text { Bobot } \\
\text { Segar Buah }\end{array}$ & $\begin{array}{c}\text { Bobot Kering } \\
\text { Brangkasan }\end{array}$ \\
\hline $\begin{array}{l}\text { Populasi } \\
\text { BPF }\end{array}$ & $-0,79^{* *}$ & $0,88^{* *}$ & $0,75^{* *}$ \\
\hline
\end{tabular}

Keterangan: ${ }^{* *}$ korelasi sangat kuat pada koefisien 0,75-0,99 (Sarwono, 2009).

Pada uji korelasi yang perlu diamati adalah arah dan kekuatan hubungannya. Tabel 3 menunjukkan populasi BPF memiliki korelasi yang sangat kuat dengan umur panen dan arah korelasinya negatif. Artinya jika populasi BPF semakin besar maka umur panen semakin kecil, dan sebaliknya. Korelasi antara populasi BPF dengan bobot segar buah juga sangat kuat dan arahnya positif. Korelasi sangat kuat juga didapati antara populasi BPF dengan bobot kering brangkasan. Artinya jika populasi BPF naik maka bobot segar buah dan bobot kering brangkasan juga naik, begitu juga jika populasi BPF turun maka bobot segar buah dan bobot kering brangkasan juga turun.

\section{KESIMPULAN}

Aplikasi mulsa plastik hitam-perak dan mulsa jerami secara signifikan meningkatkan $\mathrm{pH}$-tanah, $\mathrm{N}$-total tanah, P-tersedia tanah, total-BPF, bobot kering brangkasan, bobot segar buah per tanaman, dan mempercepat masa panen. Mulsa plastik hitam-perak dan mulsa jerami cenderung meningkatkan C-organik dan K-tertukar tanah. Terdapat korelasi yang sangat kuat antara totalBPF bobot segar buah per tanaman, dan bobot kering brangkasan dengan arah positif, sedangkan antara total-BPF dengan umur panen korelasi sangat kuat dengan arah neggatif. Perlakuan terbaik pada penelitian ini adalah mulsa plastik hitam-perak.

\section{DAFTAR PUSTAKA}

Alexander, M. 1978. Introduction to Soil Microbiology. New Delhi: Wiley Eastern Private Ltd.

Amacher, M.C., K.P. O’Neill, \& C.H. Perry. 2007. Soil Vital Signs: A New Soil Quality Index (SQI) for Assessing Forest Soil Health. Research Paper. USDA, Forest Service. Fort Collins.

Balittan (Balai Penelitian Tanah). 2005. Petunjuk Teknis Analisis Kimia Tanah, Tanaman, Air, dan Pupuk. Bogor: Badan Penelitian dan Pengembangan Pertanian.

Basyaruddin. 1982. Penelaahan Serapan dan Pelepasan Fosfat dalam Hubungannya dengan Kebutuhan Tanaman Jagung (Zea mays L.) pada Tanah Ultisol dan Andisol. Tesis. Bogor: Program Pascasarjana. IPB.

Creamer, N.G., M.A. Bennett, B.R. Stimer, \& J. Cardina. 1996. A Comparison of Four Processing Tomato Production System Differing in Cover Crop and Chemical Input. J.Amer. Soc.Hort.Sci.12 (3), 557-568.

Diaz-Perez, J.C. 2009. Rootzone Temperature, Plant Growth, and Yield of Broccoli (Brassica 
oleracea Plenck. Var. Italica) as Affected by Plastic Film Mulch. Scientia Horticulturae. 123(2), 156-163.

Dong, H.Z.,W.J Li, W. Tang, \& D.M. Zhang. 2009. Early Plastic Mulching Increases Stand Establishment and Lint Yield of Cotton in Saline Fields. Field Crop Res. 111(3), 296275.

Fang, S., B. Xie, \& J. Liu. 2008. Soil Nutrient Availability, Poplar Growth and Biomass Production on Degraded Agricultural Soil under Fresh Grass Mulch. Forest Ecology and Management. 255(5-6), 1802-1809.

Fardani, S. 2012. Pengaruh Proporsi Penambahan Kompos BioPA dan Mulsa Jerami terhadap Serapan Hara Na, Mg, serta Kandungan Klorofil Tanaman Kacang Hijau (Phaseolus radiatus L.) yang Ditanam di Kawasan Pantai Pandansari Bantul. UNY Press. Yogyakarta.

Gardner, F.P., R.B. Pearce, \& R.L. Mitchell. 1991. Fisiologi Tanaman Budidaya. UI Press. Jakarta.Lamont, W.J. 1993. Plastic Mulches for The Production of Vegetable Crops. Hort. Technology. 3(1), 35-39.

Hanafiah, A.S., T. Sabrina, \& H. Guchi. 2009. Biologi dan Ekologi Tanah. Medan: USU Press.

Hartatik, W., \& L.R. Widowati. 2006. Pupuk Organik dan Pupuk Hayati (Organic Fertilizer and Biofertilizer). Balai Besar Litbang Sumberdaya Lahan Pertanian, Badan Penelitian dan Pengembangan Pertanian. Bogor.

Hassan, S.A., R.Z. Abidin, \& M.F. Ramlan. 1995. Growth and Yield of Chilli (Capsicum annuum L.) in Response to Mulching and Potassium Fertilization. Pertanika J. Trop. Agric. Sci. 18(2), 113-117.

Hayati, Y. 2016. Budidaya Cabai Keriting dalam Pot. BPTP. Aceh.

Keller, J., \& R.D. Bleisner. 1990. Sprinkler and Tricle Irigation. AVI Publishing Company Inc. Wesport Connecticut.

Lamont, W.J. 1993. Plastic Mulches for The Production of Vegetable Crops. Hort. Technology. 3(1), 35-39.

Liang, Y.L., Xing W., Juan-juan Z., Mao-Juan Z., \& Qiang P. 2011. Response of Hot Pepper (Capsicum annuum L.) to Mulching Practices under Planted Greenhouse Condition. Agricultural Water Management. 99: 111-120.

Munir, M. 1996. Karakteristik, Klasifikasi, dan Pemanfaatannya. Pustaka Jaya. Jakarta.

Nariratih, I., M.M.B. Damanik, \& G. Sitanggang. 2013. Ketersediaan Nitrogen pada Tiga Jenis Tanah Akibat Pemberian Tiga Bahan Organik dan Serapannya pada Tanaman Jagung. Jurnal Online Agroekoteknologi. 1(3): 479-488.

Noorhadi, \& Sudadi. 2003. Kajian Pemberian Air dan Mulsa. J. Ilmu Tanah dan Lingkungan. 4(1), 41-49.

Notohadiprawiro, T. 1983. Persoalan Tanah Masam dalam Pembangunan Pertanian di Indonesia. Makalah pandukung pada seminar Pertanian Dies Natalis UGM ke-34. Universitas Gadjah Mada. Yogyakarta.

Notohadiprawiro, T., S. Soekodarmodjo, \& E. Sukana. 1984. Pengelolaan Kesuburan Tanah dan Efisiensi Pemupukan. Ceramah pada Pertemuan Alih Teknologi, Dinas Pertanian Tanaman Pangan Provinsi Dati I Jawa Tengah, di Pati. 20-22 Agustus 1984. Universitas Gadjah Mada. Yogyakarta.

Peraturan Menteri Pertanian. Nomor 70/Permentan/SR.140/10/2011 tentang Pupuk Organik, Pupuk Hayati, dan Pembenah Tanah.

Premono, M.E. 1994. Jasad Renik Pelarut Fosfat Pengaruhnya terhadap P-Tanah dan Efisiensi Pemupukan P Tanaman Tebu. Bogor: Program Pascasarjana. IPB.

Romic, D., M. Romic, J. Borosic, \& M. Poljak. 2003. Mulching Decreases Nitrate Leaching in Bell Pepper (Capsicum annuum L.) Cultivation. Agricultural Water Management. 60: 87-97.

Sarwono J. 2009. Statistik Itu Mudah: Panduan Lengkap Belajar Komputasi Statistik (Menggunakan SPSS 16). Yogyakarta: Penerbit Andi.

Sukristiyonubowo, Mulyadi, P. Wigena, \& A. Kusno. 1993. Pengaruh Penambahan Bahan Organik, Kapur dan Pupuk NPK terhadap Sifat Kimia Tanah dan Hasil Kacang Tanah. Pemberitaan Penelitian Tanah dan Pupuk 11: 1-6.

Tarara, J.M. 2000. Microclimate Modification with Plastic Mulch. HortScience. 35(2), 169180. 
Triyono, K. 2007. Pengaruh Sistem Pengolahan Tanah dan Mulsa terhadap Konservasi Sumber Daya Tanah. INNOFARM: Jurnal Inovasi Pertanian. 6(1), 11-21.

Vos, J.G.M. 1994. Integrated Crop Management of Hot Pepper (Capsicum spp.) Under Tropical Lowland Conditions: Effects of Mulch on Crop Performance and Production (PhD Thesis). Wageningen Agricultural University. p95-109.

Zou, X.X., Y.Q. Ma, R.Y. Liu, Z.Q. Zhang, W.C. Cheng, X.Z. Dai, X.F. Li, \& Q.C. Zhou. 2007. Combining Ability Analyses of Net Photosynthesis Rate in Pepper (Capsicum annuum L.). Agric. Sci. China. 6(2), 159-166. 